\title{
A Note on Editorial Practice
}

Original orthography has been retained in all quotations from early modern texts and facsimile editions, except that I have modernized $i, j, u$, and $v$.

For the reader's convenience I refer as much as possible to the modern edition of John Foxe's Actes and Monuments, ed. Stephen Reed Cattley (London, 1837-41). All references to $A \mathcal{E} M$ are to this edition. When I do cite sixteenth-century editions of Foxe, I add the date to my abbreviation: $A \mathcal{E} M\left({ }^{6} 5_{3}\right), A \mathcal{E} M(1570)$. In general, I use the modern edition and translation of John Calvin's Institutes of the Christian Religion, trans. Ford Lewis Battles, ed. John T. McNeill, 2 vols. (Philadelphia: Westminster, 1960). I abbreviate this edition as Institutes. On the few occasions when I cite the 1562 English edition of the Institutes translated by Thomas Norton, I include this date.

When quoting from the dramatic texts, I have omitted full citations of passages of less than a line of blank verse to avoid excessive editorial interruptions that might impede the flow of my argument. 

Staging Reform, Reforming the Stage 
